\title{
PENURUNAN ANGKA PEROKSIDA DAN ASAM LEMAK BEBAS (FFA) \\ PADA PROSES Bleaching MINYAK GORENG BEKAS OLEH KARBON AKTIF POLONG BUAH KELOR (Moringa Oliefera. Lamk) DENGAN AKTIVASI NaCl
}

\author{
Siti Aisyah ${ }^{1}$, Eny Yulianti $^{1}$, A. Ghanaim Fasya ${ }^{1}$ \\ ${ }^{1}$ Jurusan Kimia Fakultas Sains dan Teknologi UIN Maliki Malang
}

\begin{abstract}
ABSTRAK
Pemurnian minyak goreng bekas dalam penelitian ini terdiri dari tiga tahap yaitu despicing, netralisasi, dan bleaching menggunakan karbon aktif polong buah kelor. Pembuatan karbon aktif yang digunakan meliputi tiga tahap yaitu dehidrasi, aktivasi kimia dengan perendaman dalam larutan $\mathrm{NaCl} 15 \%$ dan 30 $\%$, dan karbonisasi dalam reaktor fluida pada suhu $650{ }^{\circ} \mathrm{C}, 700{ }^{\circ} \mathrm{C}$ dan $750{ }^{\circ} \mathrm{C}$ selama 120 menit dalam medium gas $\mathrm{N}_{2}$. Minyak goreng bekas dan minyak goreng hasil tiap tahap proses pemurnian dianalisa angka peroksida dengan metode iodometri dan FFA dengan metode titrasi asam basa. Hasilnya menunjukkan bahwa penurunan angka peroksida terbesar terjadi pada proses bleaching KA.30\% dengan suhu $650{ }^{\circ} \mathrm{C}$ yaitu dari 6,80 meq/kg menjadi 0,25 meq/kg, sedangkan FFA mengalami penurunan terbesar pada proses netralisasi yaitu dari 0,35\% menjadi 0,16\%. Hal ini menunjukkan bahwa karbon aktif polong buah kelor sangat efektif dalam menurunkan angka peroksida dan FFA pada minyak goreng bekas.
\end{abstract}

Kata Kunci : Aktivasi Kimia, FFA, Karbon Aktif, Minyak Goreng Bekas, Peroksida, Polong Buah Kelor

\section{PENDAHULUAN}

Minyak merupakan medium penggoreng bahan pangan yang banyak dikonsumsi masyarakat luas. Kurang lebih 290 juta ton minyak dikonsumsi tiap tahun. Banyaknya permintaan akan bahan pangan digoreng merupakan suatu bukti yang nyata mengenai betapa besarnya jumlah bahan pangan digoreng yang dikonsumsi manusia oleh lapisan masyarakat dari segala tingkat usia. Tujuan penggorengan dalam bahan pangan sebagai medium penghantar panas, memperbaiki rupa dan tekstur fisik bahan pangan, memberikan cita rasa gurih, menambah nilai gizi dan kalori dalam bahan pangan (Ketaren, 2005).

Pemakaian minyak goreng secara berulang dengan suhu panas yang tinggi akan mengalami perubahan sifat fisikokimia (kerusakan minyak) seperti warna, bau, meningkatnya bilangan peroksida dan asam lemak bebas (FFA), serta banyaknya kandungan logam. Kerusakan minyak yang utama adalah karena peristiwa oksidasi, hasil yang diakibatkan salah satunya adalah terbentuknya peroksida dan aldehid. Peroksida dapat mempercepat proses timbulnya bau tengik dan flavor yang tidak diikehendaki dalam bahan pangan, jika jumlah peroksida dalam bahan pangan lebih besar dari $2 \mathrm{meq} / \mathrm{kg}$ akan bersifat sangat beracun dan tidak dapat dimakan. Minyak goreng yang demikian sudah tidak layak untuk dikonsumsi karena dapat menyebabkan penyakit seperti kanker, menyempitnya pembuluh darah dan gatal pada tenggorokan (Ketaren, 2005).

Penelitian pengolahan minyak goreng bekas telah banyak dilakukan dan banyak juga yang menghasilkan temuan dalam bentuk paten. Proses pengolahan minyak goreng bekas telah dilakukan oleh Wulyoadi, dkk., (2004) dengan menggunakan membran. Hasil yang diperoleh menunjukkan bahwa minyak goreng hasil pemurnian mengalami penurunan bilangan asam dan peroksida, namun belum memenuhi persyaratan Standar Nasional Indonesia (SNI). Penelitian yang sama dilakukan oleh Sumarni, dkk., (2004), dengan menggunakan bentonit dan arang aktif untuk penjernihan minyak goreng bekas. Hasilnya menunjukkan bahwa bilangan asam dan peroksida juga mengalami penurunan, namun minyak yang dihasilkan 
belum memenuhi spesifikasi SNI (Widayat, dkk., 2006).

Hasil penelitian di atas, di dukung oleh penelitian Taufiq (2007), tentang pemurnian minyak goreng bekas menggunakan arang biji kelor yang dapat digunakan untuk menurunkan nilai FFA dan angka peroksida pada minyak goreng bekas. Penelitian Muallifah (2009) tentang penentuan angka asam thiobarbiturat dan angka peroksida pada minyak goreng bekas dengan karbon aktif biji kelor yang telah diaktivasi kimia dengan larutan $\mathrm{NaCl}$ pada suhu $500{ }^{\circ} \mathrm{C}$ selama 2 jam dapat menurunkan angka asam thiobarbiturat dan angka peroksida pada minyak goreng bekas. Angka peroksida dan FFA pada penelitian Taufiq dan Muallifah belum memenuhi SNI, maka penelitian tentang pembuatan karbon aktif dari polong buah kelor dengan aktivasi kimia $\mathrm{NaCl}$ dan variasi aktivasi fisika (variasi temperatur) pada medium nitrogen menarik dilakukan sehingga dapat meningkatkan nilai tambah karbon aktif dari polong buah kelor dan potensi pemanfaatan karbon aktif polong buah kelor lebih luas. MCconnacchie (1996) menyebutkan bahwa polong buah kelor dapat digunakan sebagai karbon aktif.

Salah satu alternatif pemecahan masalah tersebut adalah mengolah minyak goreng bekas menggunakan polong buah kelor (Moringa oleifera Lamk) sebagai adsorben yang tersedia secara lokal. Proses adsorbsi merupakan salah satu untuk memperbaiki kualitas minyak goreng bekas, yaitu dengan penambahan adsorben yang dapat dicampur langsung dengan minyak, dilanjutkan dengan pengadukan dan penyaringan (Ketaren, 2005)

\section{METODE PENELITIAN}

\subsection{Pelaksanaan Penelitian}

Penelitian ini dilaksanakan pada bulan Januari-Maret 2010 di laboratorium Jurusan Kimia Fakultas Sains dan Teknologi Universitas Islam Negeri Maulana Malik Ibrahim Malang dan dilaboratorium Jurusan Kimia Fakultas MIPA, Universitas Brawijaya.

\subsection{Bahan dan Alat Penelitian}

Bahan utama yang digunakan dalam penelitian ini adalah polong buah kelor yang sudah tua dan kering dan minyak goreng bekas dari minyak goreng curah. Bahan-bahan kimia yang digunakan dalam penelitiaan ini adalah aquades, $\mathrm{NaOH} 16 \%$, etanol teknis $96 \%$, Kloroform, larutan pati $1 \%$, asam asetat, natrium thiosulfat $\left(\mathrm{Na}_{2} \mathrm{SO}_{3}\right) 0,1 \mathrm{~N}, \mathrm{NaCl} 15 \%$ dan $30 \%, \mathrm{HCl} 0.1 \mathrm{M}$, indikator pp $1 \%$, dan larutan jenuh KI. Sedangkan alat-alat yang digunakan untuk proses pembuatan karbon aktif adalah reaktor fluida yang dialiri gas $\mathrm{N}_{2}$ dan ayakan 120-250 Mesh. Alat yang digunakan pada proses pemurnian minyak goreng bekas adalah hot plate, beaker glass $1000 \mathrm{ml}$, magnetik stirer, corong pisah, kertas saring dan kain saring. Alat yang digunakan untuk analisa peroksida dan FFA adalah seperangkat alat gelas, buret, erlenmeyer, statif, neraca analitik.

\section{CARA KERJA}

\subsection{Persiapan Sampel}

Polong buah kelor yang tua dan kering (berwarna coklat) sebanyak 50 gram dicuci dengan aquades selanjutnya dikeringkan pada suhu $105{ }^{\circ} \mathrm{C}$ sampai berat konstan kemudian ditimbang sebanyak 6,25 gram.

\subsection{Pembuatan Karbon aktif}

\section{a. Aktivasi Kimia (Yulianto, 2005)}

Enam koma dua puluh lima $(6,25)$ gram polong buah kelor yang sudah kering direndam dalam larutan $\mathrm{NaCl}$ 30\% dan $15 \%$ dengan ratio 1:4 (b/v) selama 5 jam, kemudian disaring dan dikeringkan dalam oven pada suhu $105{ }^{\circ} \mathrm{C}$ sampai kering.

\section{b. Karbonisasi (Yulianto, 2005)}

Hasil proses perendaman dikarbonisasi dalam fluidazed bed reactor pada suhu $650{ }^{\circ} \mathrm{C}$, $700{ }^{\circ} \mathrm{C}$ dan $750{ }^{\circ} \mathrm{C}$ selama 120 menit dalam medium gas $\mathrm{N}_{2}$, agar polong buah kelor menjadi arang/karbon. Arang yang terbentuk ditumbuk dengan mortar sampai halus, kemudian diayak dengan menggunakan ayakan berukuran 120-250 mesh. Arang yang digunakan dalam pembuatan karbon aktif ini 
adalah arang yang lolos dari 120 mesh dan tertahan pada ayakan 250 mesh.

\section{c. Pencucian (Yulianto, 2005)}

Karbon aktif yang dihasilkan dicuci dengan $100 \mathrm{~mL} \mathrm{HCl} \mathrm{0,1} \mathrm{M,} \mathrm{dilanjutkan} \mathrm{dengan}$ pencucian menggunakan air panas sampai $\mathrm{pH}$ netral, setelah dicuci karbon aktif dikeringkan pada suhu $110{ }^{\circ} \mathrm{C}$ sampai kering.

\subsection{Pemurnian Minyak Goreng Bekas}

\section{a. Despicing (Ketaren, 2005)}

Ditimbang sebanyak 500 gram minyak goreng bekas kemudian ditambahkan air dengan komposisi minyak:air (1:1) ke dalam gelas beaker $1000 \mathrm{~mL}$, selanjutnya dipanaskan sampai air dalam gelas beaker tinggal setengahnya, lapisan minyak diambil, bisa dibantu dengan corong pisah. Diendapkan dalam corong pemisah selama 1 jam, kemudian fraksi air pada bagian bawah dipisahkan sehingga diperoleh fraksi minyak, setelah itu dilakukan penyaringan dengan kain bersih untuk memisahkan kotoran yang tersisa.

\section{b. Netralisasi (Ketaren, 2005)}

Minyak goreng hasil proses despicing sebanyak 450 gram dimasukan ke dalam beaker glass kemudian dipanaskan pada suhu $35{ }^{0} \mathrm{C}$ kemudian ditambahkan $18 \mathrm{ml}$ larutan $\mathrm{NaOH} 16$ $\%$ dengan suhu ditingkatkan $40{ }^{0} \mathrm{C}$ sambil diaduk dengan magnetik stirer selama 10 menit, kemudian didiamkan 10 menit sampai dingin dan dipisahkan minyak dari sabun dengan cara disaring menggunakan kain.

\section{c. Bleaching (Yulianti, 2009)}

Minyak goreng hasil netralisasi sebanyak 200 gram dipanaskan sampai suhu 70 ${ }^{0} \mathrm{C}$, dimasukkan serbuk karbon aktif biji kelor $75 \mathrm{mg}$ dengan suhu ditingkatkan $100{ }^{\circ} \mathrm{C}$ sambil dilakukan pengadukan dengan magnetik stirer selama 60 menit. Selanjutnya disaring dengan kertas saring.

\subsection{Penentuan Peroksida (AOAC, 1990)}

Minyak goreng pada tiap tahap pemurnian masing-masing ditimbang 5 gram dan dimasukkan ke dalam erlenmeyer $250 \mathrm{~mL}$ kemudian ditambahkan $30 \mathrm{~mL}$ larutan asam asetat-kloroform (3:2), dikocok sampai bahan terlarut semua, selanjutnya ditambahkan $0,5 \mathrm{~mL}$ larutan jenuh KI dengan erlenmeyer dibuat tertutup. Didiamkan selama 1 menit sambil digoyang, setelah itu ditambahkan $30 \mathrm{~mL}$ aquades. Campuran dititrasi dengan $0,01 \mathrm{~N}$ $\mathrm{Na}_{2} \mathrm{SO}_{3}$ sampai warna kuning hampir hilang, ditambahkan $0,5 \mathrm{~mL}$ larutan pati $1 \%$ dan dititrasi kembali sampai warna biru mulai hilang. Dihitung angka peroksida yang dinyatakan dalam mili-equivalen dari peroksida dalam setiap $1000 \mathrm{~g}$ sampel.

$$
\text { AngkaPeroksida }=\frac{m l . \mathrm{Na}_{2} \mathrm{~S}_{2} \mathrm{O}_{3} \times N . \text { thio } \times 1000}{\text { bobotsampel }(\text { gram })}
$$

Keterangan:

meq/kg : kadar angka peroksida

ml. $\mathrm{Na}_{2} \mathrm{~S}_{2} \mathrm{O}_{3}$ : volume titran $\mathrm{Na}_{2} \mathrm{~S}_{2} \mathrm{O}_{3}$

N. $\mathrm{Na}_{2} \mathrm{~S}_{2} \mathrm{O}_{3}$ : Normalitas larutan $\mathrm{Na}_{2} \mathrm{~S}_{2} \mathrm{O}_{3}$

\subsection{Penentuan FFA (AOAC, 1990)}

Ditimbang sebesar 14 gram minyak goreng pada tiap tahap pemurnian dan dimasukkan ke dalam erlenmeyer $250 \mathrm{ml}$, selanjutnya ditambahkan $25 \mathrm{ml}$ etanol $95 \%$ dan dipanaskan pada suhu $40{ }^{\circ} \mathrm{C}$, setelah itu ditambahkan $2 \mathrm{ml}$ indikator pp, dilakukan titrasi dengan larutan $0,05 \mathrm{M} \mathrm{NaOH}$ sampai muncul warna merah jambu dan tidak hilang selama 30 detik.

$$
\% F F A=\frac{m l \mathrm{NaOH} \times \mathrm{M} \mathrm{NaOH} \times \mathrm{BM}}{\text { berat sampel } \times 1000} \times 100
$$

Keterangan:

$\begin{array}{ll}\text { \% FFA } & : \text { Kadar asam lemak bebas } \\ \mathrm{ml} \mathrm{NaOH} & : \text { Volume titran } \mathrm{NaOH} \\ \mathrm{MnaOH} & : \text { Molaritas larutan } \mathrm{NaOH} \\ & \text { mol/L) } \\ \mathrm{BM} & : \text { Berat molekul asam lemak } \\ & (\text { asam lemak palmitat) } 256 \\ & \mathrm{g} / \mathrm{mol}\end{array}$

\subsection{Analisis Data}

Analisis data pada penelitian ini dilakukan dengan cara mendeskripsikan data- 
data yang diperoleh dalam bentuk tabel untuk mengetahui penurunan angka peroksida dan FFA tiap tahap proses pemurnian kemudian dibandingkan dengan minyak goreng baru, minyak goreng bekas, minyak hasil despicing, minyak hasil netralisasi dan minyak hasil bleaching dan ditampilkan dalam bentuk grafik.

\section{HASIL DAN PEMBAHASAN \\ 4.1 Pembuatan Karbon Aktif}

Penelitian ini diawali dengan pembuatan karbon aktif dari polong buah kelor. Pembuatan karbon aktif polong buah kelor dilakukan melalui beberapa tahapan yaitu : dehidrasi, aktivasi dan karbonisasi. Dehidrasi merupakan proses menghilangkan kandungan air polong buah kelor dengan dipanaskan pada suhu 105 ${ }^{\circ} \mathrm{C}$ sampai benar-benar kering. Sebelum dipaskan polong buah kelor dipotong kecilkecil kira-kira ukuran $3 \mathrm{~cm}$, dicuci dengan aquades untuk menghilangkan pengotorpengotornya. Proses dehidrasi ini dilakukan untuk menguapkan seluruh kandungan air yang ada pada polong buah kelor. Polong buah kelor yang digunakan untuk pembuatan karbon aktif harus bersih dan berasal dari polong yang sudah tua karena kadar airnya lebih sedikit sehingga dalam proses karbonisasi, pembentukan arang yang optimal akan berlangsung baik dan merata dan tidak menghasilkan banyak asap.

Tahap kedua adalah aktivasi kimia, pada penelitian ini menggunakan larutan $\mathrm{NaCl}$ sebelum proses karbonisasi. Perendaman menggunakan $\mathrm{NaCl}$ sebelum proses karbonisasi bertujuan untuk mengurangi tar yang dihasilkan pada proses selanjutnya yaitu proses karbonisasi dan untuk menghasilkan pori-pori dengan ukuran yang sama, karena selama proses perendaman selulosa yang terkandung pada polong buah kelor mengalami perenggangan ikatan antara tiap-tiap atom $\mathrm{C}$ nya, hal ini mengakibatkan polong buah kelor lebih mengembang karena $\mathrm{NaCl}$ masuk ke poripori selulosa sehingga mempermudah degradasi molekul organik pada saat proses karbonisasi dan pori-pori karbon yang dihasilkan sama besar dengan molekul $\mathrm{NaCl}$. Larutan $\mathrm{NaCl}$ yang digunakan yaitu $30 \%$ dan $15 \%$ selama 5 jam, kemudian disaring dan dikeringkan dalam oven pada suhu $105{ }^{\circ} \mathrm{C}$ sampai benar-benar kering. Larutan $\mathrm{NaCl}$ adalah aktivator kimia pada pembuatan karbon aktif yang merupakan senyawa activating agent. Sebagian besar bahan yang digunakan untuk pembuatan karbon aktif mengandung selulosa, karena aksi dari zat pengaktif, selulosa mengalami perenggangan ikatan antara tiap-tiap atom $\mathrm{C}$ nya yang selanjutnya membantu dekomposisi senyawa organik oleh panas dan mengurangi pembentukan tar pada proses karbonisasi. Tar merupakan senyawa hidrokarbon pengotor sisa dari hasil proses pembakaran suatu bahan mentah.

Perendaman $\mathrm{NaCl}$ sebelum karbonisasi membantu menghilangkan tar yang jumlahnya besar dan menghasilkan pori-pori dengan ukuran yang sama pada proses karbonisasi. Hal ini dikarenakan pada proses karbonisasi biasanya terjadi pembentukan tar yang besar dan akan menutupi pori-pori arang yang mulai terbentuk sehingga menyebabkan luas permukaan spesifiknya menjadi kecil, dengan demikian semakin sedikit tar yang terbentuk, maka semakin besar luas permukaan spesifiknya.

Tahap ketiga adalah karbonisasi (pengarangan). Karbonisasi pada penelitian ini dilakukan pada suhu $650{ }^{\circ} \mathrm{C}, 700{ }^{\circ} \mathrm{C}$ dan 750 ${ }^{\circ} \mathrm{C}$ karena karbonisasi adalah suatu proses pirolisis (pembakaran) tak sempurna dengan udara terbatas dari bahan yang mengandung karbon, biasanya pada suhu $500-800 \quad{ }^{\circ} \mathrm{C}$ pembentukan struktur pori dimulai. Tujuan dari proses karbonisasi ini adalah untuk menghasilkan arang yang mempunyai daya serap dan srtuktur yang rapi.

Proses karbonisasi pada penelitian ini dilakukan pada suhu $650{ }^{\circ} \mathrm{C}, 700{ }^{\circ} \mathrm{C}$ dan 750 ${ }^{\circ} \mathrm{C}$ selama 120 menit dalam medium gas $\mathrm{N}_{2}$. Karbonisasi dilakukan dengan menggunakan alat karbonisasi reaktor fluida berbentuk pemanas silinder yang dipanaskan pada seluruh bagiannya secara merata, dan dilengkapi dengan tabung gas $\mathrm{N}_{2}$ sehingga arang yang dihasilkan dari proses karbonisasi ini homogen, 
dan pada proses karbonisasi ini aliran oksigen dalam tabung dibatasi untuk menghindari oksidasi karbon oleh oksigen dengan cara mengalirkan gas $\mathrm{N}_{2}$. Aliran gas $\mathrm{N}_{2}$ merupakan salah satu aktivasi fisika dalam pembuatan karbon aktif selain dipanaskan pada suhu yang tinggi. Gas $\mathrm{N}_{2}$ akan mendorong udara yang ada dalam tabung aktivasi dan mengusir tar yang dihasilkan pada proses karbonisasi sehingga dapat mengembangkan struktur rongga pada karbon.

Penelitian ini menggunakan gas nitrogen selama proses karbonisasi pada suhu $650{ }^{\circ} \mathrm{C}$, $700{ }^{\circ} \mathrm{C}$ dan $750{ }^{\circ} \mathrm{C}$ dan dilakukan selama 2 jam agar proses karbonisasi dapat berlangsung sempurna yaitu berupa pemindahan bahanbahan volatil dan tar keluar dari dalam pori. Nitrogen merupakan gas yang inert sehingga pembakaran karbon menjadi abu dan oksidasi oleh pemanasan lebih lanjut dapat dikurangi. Selain itu dengan aktivasi gas akan mengembangkan struktur rongga yang ada pada arang sehingga memperluas permukaannya, menghilangkan konstituen yang mudah menguap dan membuang tar atau hidrokarbon pengotor pada arang. Adanya gas nitrogen ini dapat mengurangi oksigen dalam ruangan aktivasi, sehingga tekanan dalam ruangan akan kecil dan pada suhu yang rendah proses karbonisasi tidak membutuhkan suhu yang tinggi.

Karbon aktif yang dihasilkan kemudian ditumbuk sampai halus, hal ini bertujuan untuk memperbesar luas permukaan karbon, sehingga mampu menyerap lebih banyak. Karbon aktif selanjutnya diayak dengan ukuran 120-250 mesh, yaitu lolos pada ukuran 120 mesh dan tertahan pada ukuran 250 mesh. Hal ini dilakukan untuk menyeragamkan ukuran pori pada karbon aktif sehingga pada proses adsorpsi efisien dan teratur. Serbuk karbon aktif kemudian di cuci dengan $\mathrm{HCl}$ untuk melarutkan mineral-mineral yang masih belum hilang pada proses karbonisasi dan dilanjutkan dengan pencucian menggunakan air panas sampai $\mathrm{pH}$ netral, hal ini bertujuan untuk menghilangkan kandungan $\mathrm{NaCl}$ yang terjebak dalam pori-pori karbon. Serbuk karbon aktif kemudian dikeringkan pada suhu $110^{\circ} \mathrm{C}$ sampai kering.

\subsection{Pemurnian Minyak Goreng Bekas}

Minyak goreng bekas merupakan minyak yang sudah tidak layak dikonsumsi, selain berwarna gelap, menimbulkan rasa gatal pada tenggorokan, mutu minyak goreng bekas sudah sangat rendah karena adanya kandungan senyawa peroksida dan asam lemak bebas yang tinggi. Hasil analisa angka peroksida dan asam lemak bebas (FFA) pada minyak goreng bekas dapat dilihat pada Tabel 1.

Tabel 1. Hasil Angka Peroksida dan FFA padaMinyak Goreng Bekas

\begin{tabular}{|c|c|c|}
\hline Analisis & Peroksida & FFA \\
\hline $\begin{array}{c}\text { Hasil } \\
\text { Penelitian }\end{array}$ & $6,80 \mathrm{meq} / \mathrm{kg}$ & $0,35 \%$ \\
\hline $\begin{array}{c}\text { Spesifikasi } \\
\text { SNI }\end{array}$ & Maks.2 meq/kg & Maks $0,3 \%$ \\
\hline
\end{tabular}

Data pada Tabel 1 telah membuktikan bahwa mutu minyak goreng bekas sudah berada di bawah standar. Hal ini menunjukkan bahwa minyak goreng bekas sudah tidak layak mengkonsumsinya. Apabila masih tetap mengkonsumsinya maka akan menyebabkan penyakit dan membahayakan bagi kesehatan tubuh. Mengandung angka peroksida 6,80 meq $/ \mathrm{kg}$ dan FFA $0,35 \%$, nilai ini sangat berbahaya bagi kesehatan karena spesifikasi SNI yang aman dikonsumsi untuk peroksida maksimum 2 meq/kg dan FFA 0,3\%.

Mutu minyak goreng dapat ditingkatkan lagi dengan menginteraksikannya dengan adsorben. Adsorben yang digunakan pada penelitian ini adalah arang aktif polong buah kelor dan minyak goreng yang digunakan adalah minyak goreng curah. Minyak goreng curah merupakan minyak yang berasal dari kelapa sawit yang proses pemurniannya dilakukan satu kali fraksinasi. Penggunaan minyak goreng curah pada penelitian ini karena fenomena kehidupan sehari-hari masyarakat menggunakan minyak goreng curah. Proses pemurnian minyak goreng bekas pada penelitian ini dilakukan 3 tahapan yaitu: proses 
pemisahan bumbu (despicing), netralisasi dan pemucatan (bleaching).

Proses despicing adalah proses yang bertujuan untuk memisahkan partikel halus tersuspensi seperti protein, karbohidrat, garam, gula dan bumbu rempah-rempah, tanpa mengurangi jumlah asam lemak bebas dalam minyak. Minyak goreng bekas dicampurkan dengan air dengan komposisi yang sama yaitu (1:1), kemudian dipanaskan hingga air tinggal yang paling menonjol dari asam karboksilat ini adalah keasamannya karena stabilisasiresonansi anion karboksilatnya, $\mathrm{RCO}_{2}^{-}$. Asam lemak pada penelitian ini direaksikan dengan larutan $\mathrm{NaOH} 16 \%$ sebagai pereaksi basa. Reaksi asam karboksilat dengan $\mathrm{NaOH}$ berlangsung melalui serangkaian tahap protonasi dan deprotonasi. Oksigen karbonil diprotonasi, $\mathrm{NaOH}$ nukleofilik menyerang karbon positif dan menghasilkan garam

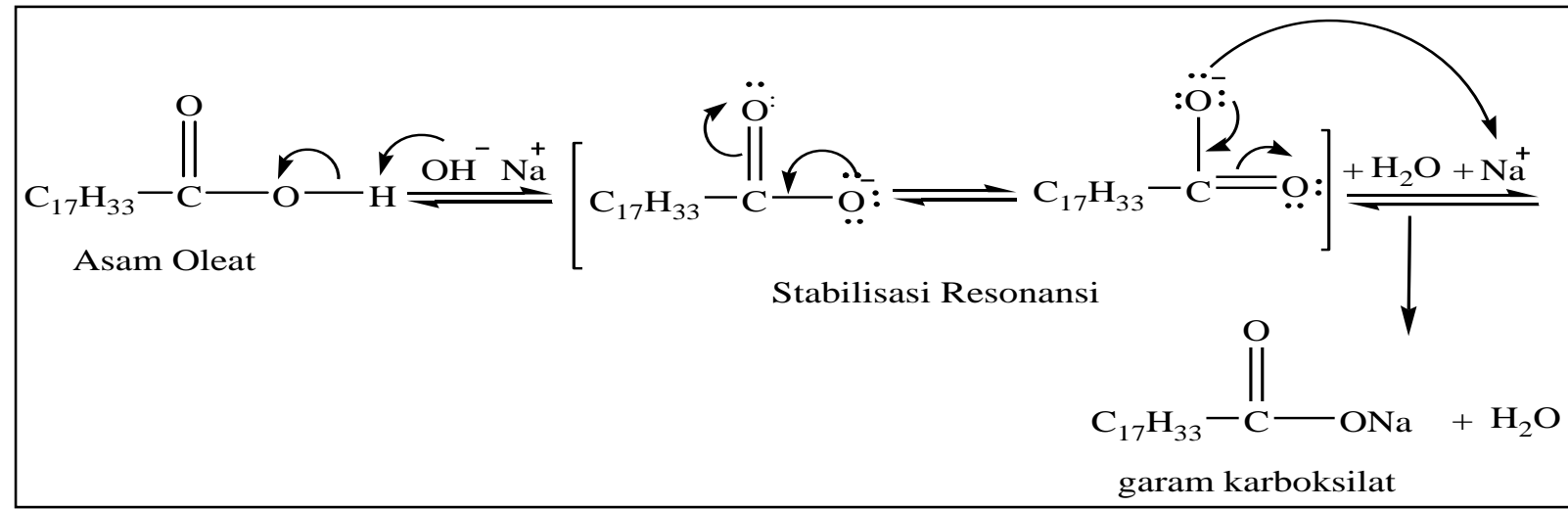

Gambar 1. Mekanisme reaksi netralisasi

setengahnya. Kotoran-kotoran tersebut (partikel halus tersuspensi) akan larut dalam air dan ikut mengendap di di bawah air, sehingga pada proses ini diperoleh minyak yang bebas bumbu, dengan warna minyak yang semula gelap/kehitaman menjadi coklat. Komposisi minyak dan air kemudian dipisahkan dengan corong pisah, terdapat dua lapisan pada proses despicing, lapisan paling atas adalah minyak dan lapisan bawah adalah air, karena berat jenis air lebih besar dari berat jenis minyak. Tahapan selanjutnya adalah proses netralisasi.

Proses netralisasi adalah suatu proses untuk memisahkan asam lemak bebas dari minyak dengan cara mereaksikan asam lemak bebas dengan basa sehingga membentuk sabun. Asam lemak yang terkandung pada minyak kelapa sawit terdiri dari asam lemak jenuh yaitu asam lemak palmitat, miristat dan stearat dan asam lemak tidak jenuh yaitu oleat dan linoleat. Kandungan asam lemak jenuh yang paling besar adalah asam lemak palmitat yaitu 40-46 $\%$ sedangkan asam lemak tidak jenuh adalah oleat yaitu 39-45 \%. Asam lemak dalam minyak goreng memiliki gugus asam karboksilat, sifat karboksilat dengan mekanisme reaksi pada gambar 1.

Proses bleaching merupakan proses pemurnian untuk menghilangkan zat-zat warna yang tidak disukai dengan menggunakan adsorben. Adsorben yang digunakan pada penelitian ini adalah karbon aktif polong buah kelor. Zat warna dalam minyak, suspensi koloid (gum dan resin) serta hasil degradasi minyak, misalnya peroksida dan asam lemak bebas akan diserap oleh permukaan karbon aktif pada proses bleaching.

Proses bleaching pada penelitian ini dilakukan dengan mereaksikan minyak goreng hasil netralisasi dengan karbon aktif polong buah kelor, yaitu sejumlah minyak dipanaskan pada suhu $70{ }^{\circ} \mathrm{C}$, kemudian dimasukkan serbuk karbon aktif polong buah kelor dengan suhu ditingkatkan $100 \quad{ }^{0} \mathrm{C}$ sambil dilakukan pengadukan dengan magnetik stirer selama 60 menit. Peningkatan suhu ini bertujuan untuk mempercepat reaksi antara karbon aktif dengan peroksida dan asam lemak bebas, sedangkan waktu dan pengadukan bertujuan untuk mencapai kesetimbangan adsorpsi, jika fase 
cairan yang berisi adsorben diam, maka difusi adsorbat melalui permukaan adsorben akan lambat, oleh karena itu diperlukan pengadukan untuk mempercepat proses adsorpsi. Pengadukan juga dimaksudkan untuk memberi kesempatan pada partikel arang aktif untuk bersinggungan dengan senyawa serapan. Selanjutnya disaring dengan kertas saring

\subsection{Hasil Analisa Peroksida}

Peroksida merupakan produk awal terjadinya kerusakan pada minyak goreng akibat terjadinya reaksi autoksidasi pada minyak. Analisa angka peroksida pada penelitian ini yaitu minyak goreng baru (minyak curah), bekas, despicing, netralisasi dan bleaching dilakukan dengan metode iodometri, dengan cara sejumlah minyak dilarutkan dalam campuran asetat:kloroform yang mengandung KI, maka akan terjadi pelepasan iodin $\left(\mathrm{I}_{2}\right)$. Iodin yang bebas dititrasi dengan natrium tiosulfat, selanjutnya ditambahkan indikator amilum sampai terbentuk warna biru, kemudian dititrasi lagi dengan natrium thiosulfat sampai warna biru hilang. Terbentuknya warna biru setelah penambahan amilum, dikarenakan struktur molekul amilum yang berbentuk spiral, sehingga akan mengikat molekul iodin maka terbentuklah warna biru. Warna biru gelap yang timbul karena terbentuknya kompleks iodinamilum. Pengukuran angka peroksida ini dapat digunakan untuk mengetahui kadar ketengikan minyak. Hasil analisa peroksida setiap tahap pemurnian dapat dilihat pada Tabel 2.

Tabel 2 menunjukkan bahwa setiap tahap pemurnian minyak goreng bekas, angka peroksida mengalami penurunan dan menurun secara signifikan pada proses bleaching. Penurunan angka peroksida pada proses despicing disebabkan karena senyawa peroksida R.COO ${ }^{\circ}$ dengan gugus karbonil $\mathrm{RC}=\mathrm{O}$ dan radikal $\mathrm{O}^{\circ}$ dengan rantai karbon pendek bersifat polar dan pada rantai karbon panjang bersifat lebih kepada nonpolar, hal ini disebabkan karena pada proses penggorengan dengan suhu tinggi ada sebagian ikatan yang putus sehingga memiliki rantai karbon pendek, senyawa peroksida dengan rantai karbon pendek akan lebih mudah larut dalam air panas dibanding dalam minyak. Air bersifat polar, sementara minyak bersifat non polar, karena beda kepolaran minyak dan air tidak bisa larut sehingga komponen polar yang ada dalam minyak bekas seperti protein, karbohidrat, garam, gula, serta bumbu rempah-rempah yang tertinggal selama menggoreng larut dalam air, sehingga setelah melalui tahapan despicing angka peroksida minyak goreng turun. Penurunan angka peroksida pada proses netralisasi juga disebabkan karena senyawa peroksida yang memiliki rantai karbon pendek larut dalam air dan disebabkan dalam asam lemak bebas terdapat sebagian kecil peroksida yang terikat, sehingga ketika asam lemak bebas terendapkan melalui proses penyabunan, ada sebagian peroksida yang ikut mengendap. Penurunan peroksida terbesar pada proses bleaching disebabkan oleh adsorpsi (penyerapan) karbon aktif polong buah kelor, karena karbon aktif polong buah kelor memiliki luas permukaan dan pori-pori yang besar, sehingga dapat mengikat dan menyerap senyawa peroksida. Data hasil penurunan angka peroksida minyak goreng baru (curah), bekas, dan hasil reprosessing disajikan Gambar 2.

Tabel 2. Angka Peroksida setiap Tahap Proses Pemurnian Minyak

\begin{tabular}{|l|c|}
\hline \multicolumn{1}{|c|}{ Minyak } & $\begin{array}{c}\text { Peroksida } \\
(\mathbf{m e q} / \mathbf{k g})\end{array}$ \\
\hline Minyak Baru & 0,15 \\
\hline Minyak Bekas & 6,80 \\
\hline Minyak Despicing & 6,45 \\
\hline Minyak Netralisasi & 4,81 \\
\hline $\begin{array}{l}\text { Minyak Bleaching } 650^{\circ} \mathrm{C} 30 \% \\
\mathrm{NaCl}\end{array}$ & 0,25 \\
\hline
\end{tabular}




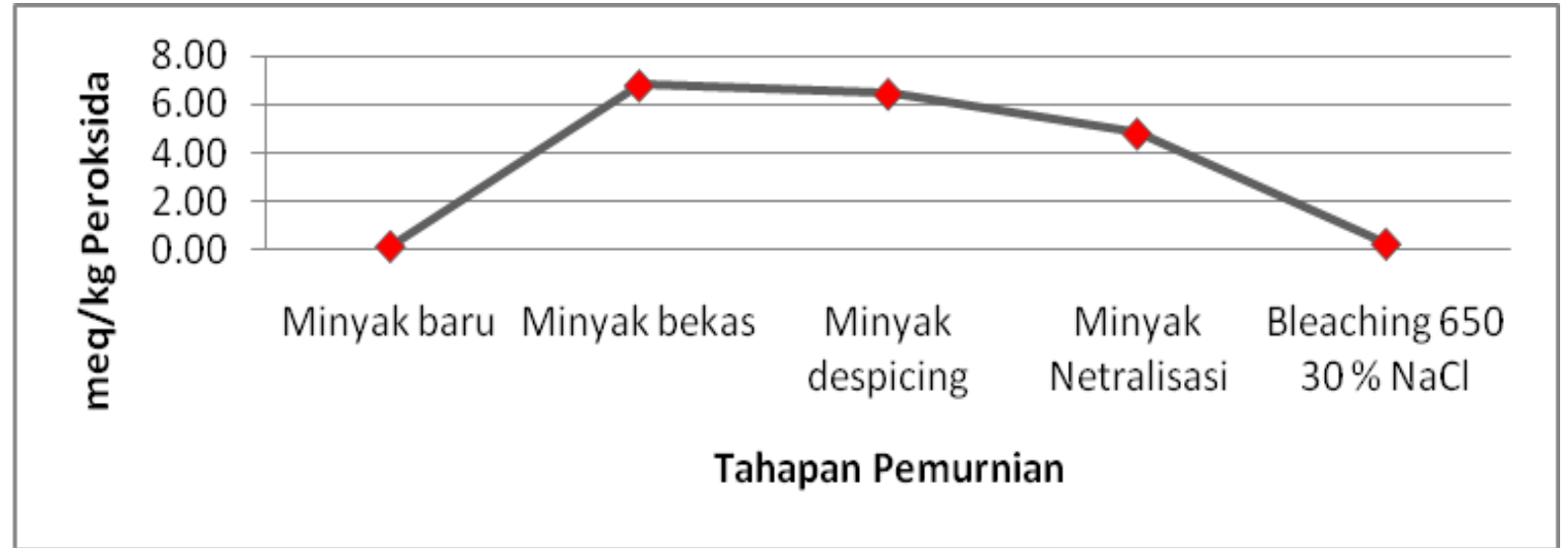

Gambar 2. Grafik jumlah peroksida tiap proses pengolahan

Tingginya angka peroksida minyak goreng bekas ini karena diakibatkan proses oksidasi pada saat proses pemasakan atau penyimpanan, sehingga terbentuklah peroksida. Reaksi pembentukan peroksida pada minyak diakibatkan oleh reaksi oksidasi oleh oksigen dengan sejumlah asam lemak tidak jenuh, dalam hal ini adalah asam lemak oleat yang terkadung sebanyak 39-45 \% pada minyak kelapa sawit, reaksi ini dipercepat oleh pemanasan.

Proses adsorpsi antara peroksida dengan karbon aktif polong buah kelor dikarenakan adanya perbedaan energi potensial antara permukaan adsorben dan zat yang diserap, baik itu melibatkan gaya fisika atau kimia. Adsorpsi fisika melibatkan gaya antarmolekuler (gaya Van der waals atau melalui ikatan hidrogen). Molekul yang terbentuk dari adsorpsi fisika terikat sangat lemah dan energi yang dilepaskan pada adsorpsi fisika relatif rendah sekitar 20 $\mathrm{Kj} / \mathrm{Mol}$, karena itu sifat adsorpsinya adalah reversible, yaitu dapat balik atau dilepaskan kembali dengan adanya penurunan konsentrasi larutan. Proses adsorpsi kimia adalah interaksi antara adsorbat dengan adsorben melibatkan pembentukan ikatan kimia (biasanya ikatan kovalen).

Interaksi antara peroksida dengan karbon aktif polong buah kelor dalam penelitian ini dimungkinkan terjadi adsorpsi secara fisika karena setiap pertikel-pertikel adsorbat yang mendekati ke permukaan adsorben melalui gaya van der walls atau ikatan hidrogen, hal ini dikarenakan adanya perbedaan energi potensial antara permukaan adsorben dan adsorbat.

Proses bleaching pada penelitian ini menggunakan karbon aktif polong buah kelor dengan variasi suhu karbonisasi dan variasi konsentrasi aktivasi $\mathrm{NaCl}$. Pengaruh variasi

suhu karbonisasi dan konsentrasi aktivasi $\mathrm{NaCl}$ terhadap penurunan angka peroksida terlihat pada tabel 3 .

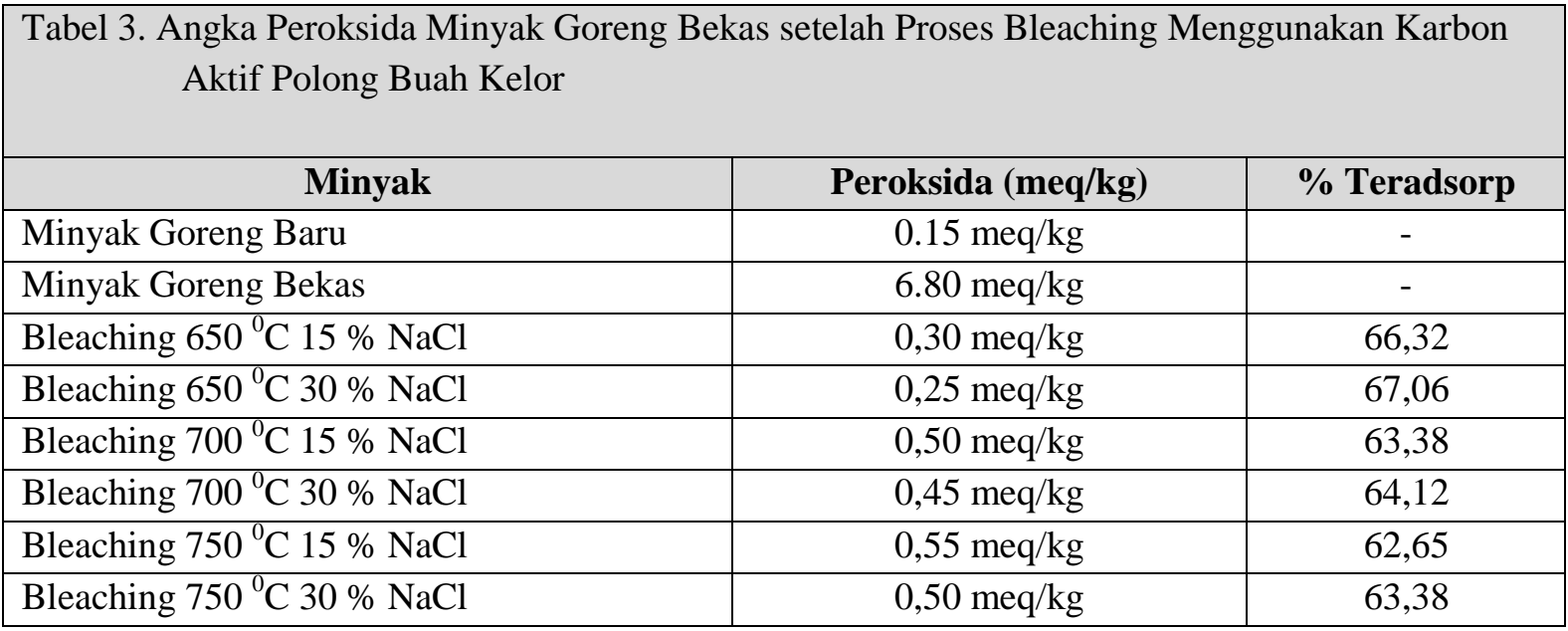


Tabel 3 menunjukkan bahwa semakin tinggi suhu karbonisasi maka penyerapan peroksida oleh karbon aktif semakin kecil, hal ini dimungkinkan dengan semakin tinggi suhu karbonisasi struktur pori karbon aktif yang dihasilkan ada yang rusak. Konsentrasi $\mathrm{NaCl} 30$ $\%$ menghasilkan karbon aktif yang memiliki luas permukan yang besar ditunjukkan dengan penyerapan peroksida besar pada konsentrasi $\mathrm{NaCl} 30 \%$ yaitu mengadsorp 67,1\% dengan angka peroksida $0,25 \mathrm{meq} / \mathrm{Kg}$.

\subsection{Analisa Asam Lemak Bebas (FFA)}

Asam lemak bebas merupakan dasar untuk mengetahui umur minyak, kemurnian minyak, dan tingkat hidrolisa. Asam lemak bebas dengan kadar lebih dari 0,2\% dari berat minyak mengakibatkan flavor yang tidak disukai dan meracuni tubuh.

Analisa asam lemak bebas minyak goreng baru, bekas, despicing, netralisasi dan bleaching dilakukan dengan metode titrasi asam basa. Sejumlah minyak dilarutkan dalam etanol, penggunaan pelarut etanol yang polar ini dimaksudkan agar asam lemak bebas yang bersifat non polar dan larut dalam minyak dapat larut pada fase yang sama dengan $\mathrm{NaOH}$. Larutan $\mathrm{NaOH}$ ini bersifat polar, sehingga pada saaat titrasi asam lemak bebas dengan $\mathrm{NaOH}$ dapat berinteraksi, karena etanol ini gugus $\mathrm{OH}$ sifatnya hidrofil (suka air) dan rantai karbon $\mathrm{CH}_{3} \mathrm{CH}_{2}$ bersifat hidrofob, kemudian dilakukan pemanasan agar larut sempurna dan ditambahkan indikator $\mathrm{pp}$, selanjutnya dititrasi dengan $\mathrm{NaOH}$ sampai terbentuk warna merah jambu yang tidak hilang selama 30 detik.

Terbentuknya warna merah jambu setelah dititrasi dengan sejumlah $\mathrm{NaOH}$ menunjukkan $\mathrm{NaOH}$ telah bereaksi sempurna dengan asam lemak bebas karena pada kenaikan pH 8-9 indikator pp yang tidak berwarna akan berubah menjadi merah. Data hasil penurunan FFA pada minyak baru, bekas, despicing, netralisasi, dan bleaching disajikan pada Tabel 4.

Tabel 4. Asam Lemak Bebas setiap Tahap Proses Pemurnian Minyak

\begin{tabular}{|l|c|}
\hline \multicolumn{1}{|c|}{ Minyak } & \% FFA \\
\hline Minyak Baru & 0,03 \\
\hline Minyak Bekas & 0,35 \\
\hline Minyak Despicing & 0,28 \\
\hline Minyak Netralisasi & 0,16 \\
\hline $\begin{array}{l}\text { Minyak Bleaching } 650^{\circ} \mathrm{C} 30 \% \\
\mathrm{NaCl}\end{array}$ & 0,05 \\
\hline
\end{tabular}

Tabel 4 menunjukan bahwa setiap tahap pemurnian minyak goreng bekas, asam lemak bebas mengalami penurunan dan menurun secara signifikan pada proses bleaching. Penurunan asam lemak bebas pada proses despicing disebabkan karena reaksi hidrolisis minyak dengan air, hal ini asam lemak bebas yang memiliki gugus karbonil dan gugus hidroksil yang bersifat polar dengan rantai karbon pendek akan larut dalam air dan bersamaan dengan air menguap pada proses pemanasan dan ikut terpisahkan pada proses pemisahan minyak dengan air.

Tabel 5. FFA Minyak Goreng Hasil Bleaching dengan Variasi Suhu Pemanasan Karbonisasi \&

Konsentrasi $\mathrm{NaCl}$

\begin{tabular}{|l|c|c|}
\hline \multicolumn{1}{|c|}{ Minyak } & \%FFA & \% Teradsorp \\
\hline Minyak Goreng Baru & 0,03 & - \\
\hline Minyak Goreng Bekas & 0,35 & - \\
\hline Bleaching T $650^{\circ} \mathrm{C} \mathrm{NaCl} 15 \%$ & 0,06 & 28,57 \\
\hline Bleaching T $650^{\circ} \mathrm{C} \mathrm{NaCl} 30 \%$ & 0,05 & 31,43 \\
\hline Bleaching $\mathrm{T} 700^{\circ} \mathrm{C} \mathrm{NaCl} 15 \%$ & 0,08 & 22,86 \\
\hline Bleaching $\mathrm{T} 700^{\circ} \mathrm{C} \mathrm{NaCl} 30 \%$ & 0,07 & 25,71 \\
\hline Bleaching $\mathrm{T} 750^{\circ} \mathrm{C} \mathrm{NaCl} 15 \%$ & 0,09 & 20 \\
\hline Bleaching $\mathrm{T} 750^{\circ} \mathrm{C} \mathrm{NaCl} 30 \%$ & 0,08 & 22,86 \\
\hline
\end{tabular}


Penurunan asam lemak bebas pada proses netralisasi disebabkan karena reaksi asam lemak bebas dengan larutan $\mathrm{NaOH}$ membentuk sabun. Proses netralisasi ini bleaching minyak mengindikasikan bahwa karbon aktif polong buah kelor memiliki situssitus aktif dengan luas permukaan yang besar.

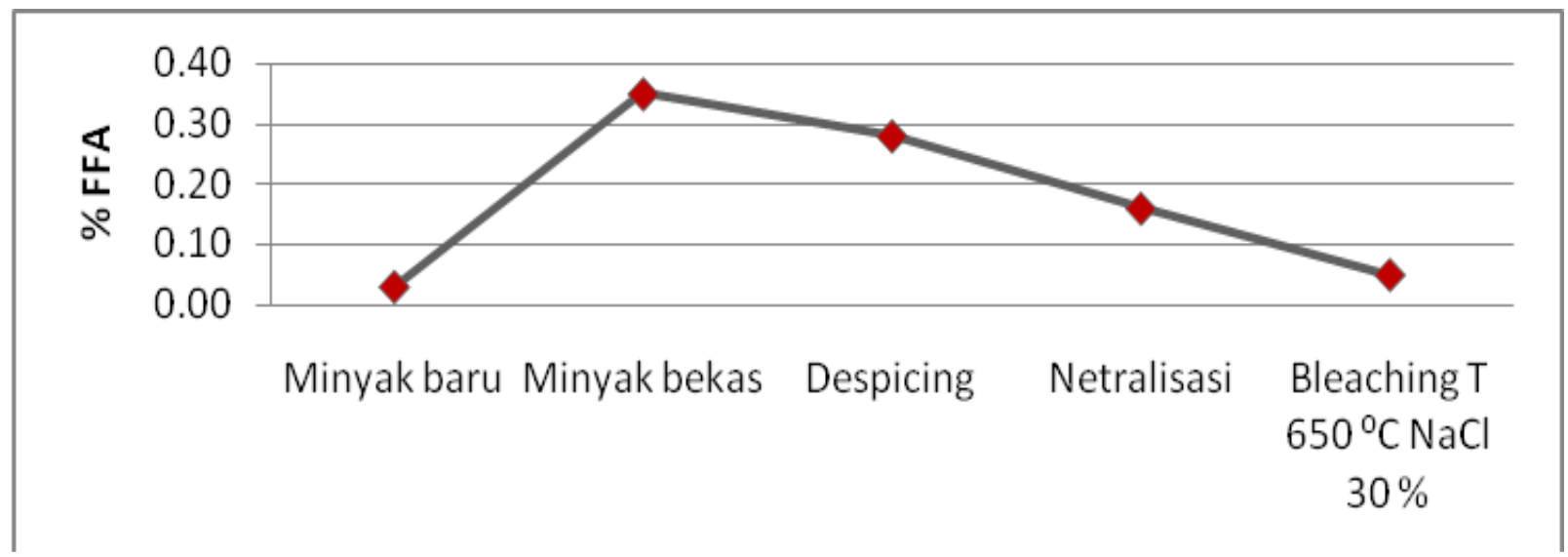

Gambar 3. Grafik Penurunan FFA setiap Tahap Pemurnian

menyumbang besar terhadap penurunan asam lemak bebas pada minyak. Penurunan asam lemak bebas secara signifikan pada proses bleaching disebabkan oleh adsorpsi (penyerapan) karbon aktif polong buah kelor, karena karbon aktif polong buah kelor memiliki luas permukaan dan pori-pori yang besar, sehingga dapat mengikat dan menyerap senyawa asam lemak bebas pada permukaannya. Data hasil penurunan asam lemak bebas minyak goreng baru (curah), bekas, dan hasil reprosessing disajikan Gambar 3.

Proses bleaching pada penelitian ini menggunakan karbon aktif polong buah kelor dengan variasi suhu karbonisasi dan variasi konsentrasi aktivasi $\mathrm{NaCl}$. Pengaruh variasi suhu karbonisasi dan konsentrasi aktivasi $\mathrm{NaCl}$ terhadap penurunan asam lemak bebas terlihat pada tabel 5 .

Data diatas menunjukkan bahwa semakin tinggi suhu karbonisasi, penyerapan FFA semakin rendah, hal ini dimungkinkan dengan semakin tinggi suhu maka karbon aktif yang dihasilkan sebagian kecil struktur pori karbon mengalami kerusakan. Hasil terbaik penurunan asam lemak bebas dicapai pada karbon aktif suhu $650{ }^{\circ} \mathrm{C}$ dengan $30 \% \mathrm{NaCl}$ yaitu $0,05 \%$. Kemampuan karbon aktif polong buah kelor menurunkan asam lemak bebas pada proses

\section{KESIMPULAN DAN SARAN \\ 5.1 Kesimpulan}

1. Setiap tahap pemurnian minyak goreng bekas mampu menurunkan angka peroksida dimana penurunan terbesar tercapai pada proses bleaching. Hasil penurunan ini berturut-turut minyak goreng bekas, despicing, netralisasi dan bleaching $650{ }^{\circ} \mathrm{C}$ konsentrasi $\mathrm{NaCl} 30 \%$ yaitu $6.80,6.45$, 4.81 dan $0.25 \mathrm{meq} / \mathrm{Kg}$

2. Setiap tahap pemurnian minyak goreng bekas mampu menurunkan asam lemak bebas dimana penurunan terbesar tercapai pada proses netralisasi disusul pada proses bleaching $650{ }^{\circ} \mathrm{C}$ konsentrasi $\mathrm{NaCl} 30 \%$. Hasil penurunan ini berturut-turut minyak goreng bekas, despicing, netralisasi dan bleaching $650{ }^{\circ} \mathrm{C}$ konsentrasi $\mathrm{NaCl} 30 \%$ yaitu $0.35,0.28,0.16$ dan $0.05 \%$ FFA.

\subsection{Saran}

1. Perlu dilakukan penelitiaan lebih lanjut untuk mengetahui adsorpsi secara kimia dengan gugus fungsi karbon polong buah kelor

2. Perlu adanya penelitiaan lebih lanjut tentang pengaruh ukuran partikel dari adsorben polong buah kelor, perbandingan aktivasi 
$\mathrm{NaCl}$ sebelum karbonisasi dan sesudah karbonisasi.

\section{DAFTAR PUSTAKA}

Amsden, J.P. 1950. Physical Chemistry For Peremedical Students. $2^{\text {th }}$ Ed. New York : McGraw Hill Book Company. P.264.

Connachie Mc.G.L, A.M. Warhurst, S.J. Pollard, UK and V. 1996. Activated carbon from Moringa husks and pods. Malawi New Delhi : Chipofya.

Fauzan Asep. 2009. Konsumsi Makanan mengandung zat Kimia dalam Perspektif Islam. Masail Fiqhiyah. Diakses tanggal 09 Nopember 2009.

Jan kowska,H.Swiatkowski,A,Chorna,J. 1991. Active Carbon. London : Horwood.

Juliandini, F dan Yulinah T. 2008. Uji Kemampuan Karbon Aktif dari Limbah Kayu Dalam Sampah Kota untuk Penyisihan Fenol. Surabaya : Institut Teknologi Sepuluh Nopember.

Ketaren, S,. 2005. Pengantar Teknologi Dan Lemak Pangan. Jakarta : Penerbit UIPress, 174, 69, 113.

Maron,S.H, dan Lando, J.B. 1974. Fundamental Of Physical Chemistry. New York : Mac Milla Publising Co. Inc PP 753, 763.

Muallifah Siti. 2009. Penentuan Angka Asam Thiobarbiturat (Tba) Dan Angka Peroksida Pada Minyak Goreng Bekas Hasil Pemurnian Dengan Biji Kelor (Moringa Oleifera, Lamk). Skripsi. Malang : Jurusan kimia, Fakultas Sains dan Teknologi, Universitas Islam Negeri Malang.

Mulek A.P. 2005. Studi Penambahan Larutan $\mathrm{NaCl}$ Pada Pembuatan Kaarbon Aktif Dari Tempurung Kelapa. Skripsi, Jurusan kimia, Fakultas MIPA, Universitas Brawijaya, Malang.

Mustafa, A, 1992, Terjemah Tafsir Al-Maraghi 7, CV. TOHA PUTRA, Semarang

Parker RS. 1996. Absorption, metabolism and transport of carotenoids. FASEB J 1996; 10: 542- 551.

Rahardjo Sugeng. 1997. Pembuatan Karbon Aktif Dari serbuk Gergajian pohon Jati Dengan $\mathrm{NaCl}$ Sebagai Bahan Pengaktif, Skripsi. Malang : Jurusan kimia, Fakultas MIPA, Universitas Brawijaya.

Sabarudin, A. 1996. Aktivasi Arang Tempurung Kelapa dengan $\mathrm{NaCl}$ dan $\mathrm{Gas} \mathrm{CO}_{2}$ dalam Reaktor Fluidasi, Skripsi. Malang : Jurusan kimia, Fakultas MIPA, Universitas Brawijaya.

Sawyer,CN, and Mc Carty,P.L. 1981. Chemistry For Engineering, Third Edition, McGraw Hill Book Company, New York, P.89.

Sembiring, M. T, Sinaga, T. S. 2003. Arang Aktif (Pengenalan dan Proses Pembuatannya), Jurusan Teknik Industri, Fakultas Teknik, Universitas Sumatera Utara.

Smisek, M., and Cerny, S. 1970. Active Carbon. New York : Elsevier Publishing Company. pp.11-22.

Silalahi, S. 2005. Studi Awal Kualitas Minyak Goreng Kelapa Sawit Pada Penggorengan Berulang Produk Tertentu, http//www. iopri.org/index. php? option= com 2005 content $\&$ task $=$ section $\& i d=91 \&$ Itemid $=47$. Diakses Tanggal 15 Februari 2007.

Taufiq Muhammad. 2007. Pemurnian Minyak Goreng Bekas (Jelantah) Menggunakan Biji Kelor (Moringa Oleifera Lamk), Skripsi. Malang : Jurusan Kimia Fakultas Sains Dan Teknologi, UIN.

Wahjuni Sri dan Betty Kostradiyanti. 2008. Penurunan Angka peroksida Minyak Kelapa Tradisional dengan Adsorben Arang Sekam padi IR 64 yang Diaktifkan dengan Kalium Hidroksida, Jurusan Kimia FMIPA Universitas Udayana, Bukit Jimbaran.

Warhurst. A.M, McConnachie. G, dan Pollard. J.T. Simon. 1997. Characterisation And Applications of Activated Carbon Produced From Moringa Oleifera Seed Husks By Single-Step Steam Pyrolysis. Department of Civil and Environmental Engineering, University of Edinburgh, King's Buildings, Pergamon, Britain.

Widayat, Suherman dan K.Haryani. 2006. Optimasi Proses Adsorbsi Minyak Goreng Bekas Dengan Adsorbent Zeolit Alam : Studi Pengurangan Bilangan Asam, Jurnal Penelitian Teknik Kimia, Volume 17 No.01 April 2006, Penerbit Universitas Diponegoro, Semarang. 
Wijana, S., Arif, H., dan Nur, H. 2005. Tekno Pangan: Mengolah Minyak Goreng Bekas. Penerbit Trubus Agrisarana. Surabaya, 2, 4, dan 5.

Winarno, F.G. 2002. Kimia Pangan Dan Gizi, Penerbit PT Gramedia Pustaka Utama. Jakarta. 95, 107.

Yulianti Eny. 2009. Adsorpsi Peroksida dan Asam Lemak Bebas (FFA) dalam (Moringa oliefera.Lamk) yang telah Diaktivasi dengan proses Pirolisis Satu Tahap. Lamlitbang, Universitas Islam Negeri Malang.

Yulianto Andri. 2005. Pembuatan Karbon Aktif Dari Kulit Kacang Tanah Dengan $\mathrm{KOH}$

Sebagai Bahan Pengaktif, Skripsi, Jurusan kimia, Fakultas MIPA, Universitas Brawijaya, Malang. 